\title{
The critical factors shaping customer shopping experiences with innovative technologies
}

\section{Marianne Ylilehto, Hanna Komulainen and Pauliina Ulkuniemi Department of Marketing, University of Oulu, Oulu, Finland}

\begin{abstract}
Purpose - The purpose of this study is to explore the customer shopping experience in the innovative technology setting. Specifically, the purpose is to understand how do innovative technologies influence the customer shopping experience?

Design/methodology/approach - This qualitative, explorative study has characteristics of a phenomenological research strategy. The data were collected from four focus groups and ten in-depth interviews with consumers. Abductive approach with an implementation of content analysis was used as a method of analysis.

Findings - The results show that there are three critical factors in customer's shopping experience in the context of innovative technologies; (1) channel choice, (2) value dimensions related to convenience and enjoyment, and (3) social interaction. All factors are highly intertwined and influence each other.

Originality/value - This study contributes to customer experience literature by offering a framework for understanding customer shopping experiences in the innovative technology setting. These findings have important implications for retail managers seeking to enhance customer experience and achieve a competitive advantage by utilizing innovative technology.
\end{abstract}

Keywords Customer experience, Retailing, Shopping, Technology, Value

Paper type Research paper

\section{Introduction}

Consumer shopping experiences are increasingly influenced by new technology (Grewal et al., 2020; Hoyer et al., 2020; Willems et al., 2017). It is not surprising that a survey by Periscope-McKinsey in 2017 discovered that 95 percent of retail CEOs consider personalizing the customer experience a strategic priority for their companies (McKinsey, 2020). The emerging technology in retailing will create new value to customers (Rangaswamy et al., 2020) and to compete efficiently in the digital era, retailers need to be willing to adopt innovations to integrate them into their operations (Pantano and Viassone, 2014). Making sense of the role of technology in developing customer experience is challenging because not all technologies are currently implemented in practice, and therefore, retailers do not know how to provide value for their customers.

At the same time, more and more studies are delving into the area of innovative technologies such as the internet of Things (IoT), virtual or augmented reality (VR/AR), artificial intelligence (AI), the Blockchain, and drones, and how these technologies shape retailing (Hoyer et al., 2020). Previous research has, for example, focused on AR in user acceptance in the online environment and increasingly in mobile usage too (Dacko, 2017; Kang, 2014; Poushneh and Vasquez-Parraga, 2017), the role of VR in virtual marketing

(C) Marianne Ylilehto, Hanna Komulainen and Pauliina Ulkuniemi. Published by Emerald Publishing Limited. This article is published under the Creative Commons Attribution (CC BY 4.0) licence. Anyone may reproduce, distribute, translate and create derivative works of this article (for both commercial and non-commercial purposes), subject to full attribution to the original publication and authors. The full terms of this licence may be seen at http://creativecommons.org/licences/by/4.0/legalcode

This work was supported by the Jenny and Antti Wihuri Foundation.

\section{Customer shopping experiences}

Received 9 February 2021 Revised 25 April 2021 31 May 2021

Accepted 2 June 2021 
BJM

16,5

662

communications and customer experience of different retail channels (Kim and Forsythe, 2008; Oh et al., 2008; Vrechopoulos et al., 2009), and blockchain research on payment systems and security from the marketing and retailing perspective (Neyer and Geva, 2017; Frey et al., 2016). The exponential growth of innovative technology strongly influences the customer experience in the shopping context, and despite the growing interest in utilizing such technology in retailing, it is not clear which particular innovation will have the most important role in shopping and which underlying factors of these technologies will influence the customer's shopping experience.

In this paper, we focus on the customer experience in the retail setting where customer experience is commonly defined as a multidimensional construct that "is holistic in nature and involves the customer's cognitive, affective, emotional, social and physical responses" (Verhoef et al., 2009, p. 32). Since the technologies are only emerging and not yet in active use in the retail context, exploring their role in customer's future shopping experience becomes a highly relevant topic. In particular, retailers should understand what their customers think of the technologies, how they will use them for shopping purposes, and how to utilize them in creating a superior customer experience. Thus, there is a call for research on what these technologies mean to the customer's shopping experience.

The purpose of this study is to explore the customer shopping experience in the innovative technology setting. The research question is: How do innovative technologies influence the customer shopping experience? To achieve the study's purpose, we first reviewed the customer experience literature in the retailing field and in relation to innovative technologies, as well as extant studies on channel choice and customer value. Based on that exercise, we formulated a theoretical framework that aids understanding customer experience in the innovative technologies setting. Having presented that framework, we report on a qualitative investigation involving focus group interviews with 17 participants and 10 in-depth interviews to examine the phenomenon empirically. Finally, the results are presented and discussed together with theoretical contributions, managerial implications, limitations of the study, and indications for future research.

The study contributes to customer experience literature by offering a framework for understanding customer's shopping experience in the novel technological setting. It will aid managers in realizing the opportunities and challenges related to the continuously changing retail environment and in planning how to utilize innovative technologies to improve the customer shopping experience.

\section{Theoretical foundations}

\subsection{Customer experience in retailing}

Customer experience has long been studied in marketing research, and researchers still have mixed views on how to fully conceptualize it. The need for a deeper understanding of the customer's experiences emerged through the seminal article by Holbrook and Hirschman (1982) who noted that experience plays an important role in consumer behavior (Edvardsson et al., 2005; Carù and Cova, 2003; Tynan and McKechnie, 2009).

The shopping experience is a term widely used in retailing research, and specifically includes the customer experience in the action of shopping. Research around this topic has focused on shopping in different channels (Dorman, 2013), the social aspect of shopping (Borges et al., 2010), and the role of technologies in the purchase journey (Willems et al., 2017). This study follows the phenomenological perspective on customer experience (see, e.g. Helkkula et al., 2012) that focuses on how the individual subjectively experiences his/her lifeworld and makes sense of this individual and social reality through a circular process involving experiential transportation back and forth in time (see Helkkula and Kelleher, 2010; Lipkin, 2016). This view on customer experience emphasizes the role of the customer as the 
central actor involved in forming both actual and imaginary experiences, and also the social and temporal aspects related to that role (Komulainen and Saraniemi, 2019). Experience is thus subjectively socially constructed, in that the experiences and the accounts of other people can affect the customer experience, and also situation-specific and contextual (Pine and Gilmore, 1998; Edvardsson et al., 2005, Dube and Helkkula, 2015). In experiential consumption, consumption involves more than mere purchasing because consumers are not only consumers but act in a situational context by seeking a purposeful meaning (Carù et al., 2007). In addition, through circular sense-making, the customer moves in time across a broad and non-linear timeline including the past, present, and future dimensions (Dube and Helkkula, 2015). Experience must thus be examined via a broad perspective covering all moments before, during and after the actual use of a service, as well as its imagined use (Heinonen et al., 2010; Helkkula et al., 2012).

\subsection{Innovative technologies and customer experience}

The exponential growth of new innovative technologies in recent years also has a strong influence on customer experience in the shopping context and many diverse innovative technologies have attracted the attention of both academics and practitioners. The key points of the rapidly growing research around innovative technologies in retailing are summarized in Table 1. This research (see Table 1) has an impact on retailing but also consumer behavior and marketing literature.

The literature review identified six key innovative technologies in retailing: augmented reality (AR), virtual reality (VR), artificial intelligence (AI), the internet of Things (IoT), the Blockchain and drones. These technologies have been predicted to play a significant role in retailing in the near future and are anticipated to change the meaning of the customer experience (Grewal et al., 2017). First, "AR is a technology that adds computer-generated enhancements atop an existing reality" (ERC, 2016). Augmented reality studies focus mainly on consumer behavior, especially user acceptance and shopping value in the online or more increasingly in mobile usage (Poushneh and Vasquez-Parraga, 2017; Smink et al., 2019; Watson et al., 2018). Barlow et al. state, "VR is the simulation of a real or imagined 3D environment that can be experienced visually or interactively in full real-time motion" (2004, p. 160), and VR research focuses on consumer satisfaction and usage motives, for example (Pizzi et al., 2019; Vrechopoulos et al., 2009; Yang and Xiong, 2019). Artificial intelligence emphasizes the creation of intelligent machines that work and react like humans, such as those specialized in speech recognition, learning, and problem-solving. Research on AI identifies the implications of AI-based technology, especially the role of voice assistants in marketing and retailing as well as AI-powered automated stores (Guzman, 2018; Hsiao and Chang, 2019; Pillai et al., 2020). The IoT is the network of physical devices embedded with connected sensory devices that enables those objects to connect and exchange data. Studies of the IoT explain the smart interactions between humans and machines in everyday life (Balaji and Roy, 2017; Hoffman and Novak, 2018; Wu et al., 2017). The Blockchain is a continuously growing list of records (blocks) that are linked and secured using cryptography, and the recent related research in retailing focuses on payment systems and security from the marketing and retailing perspective (Neyer and Geva, 2017; Frey et al., 2016). Finally, research around drones focuses on different methods of air self-service delivery (Hwang et al., 2019; Yoo et al., 2018). These innovative technologies are expected to change retailing not by specifically creating an extraordinary experience but by adding value to the shopper's ordinary experience (Carù and Cova, 2003).

\subsection{Shopping channels}

Innovative technologies have a direct influence on channels. As more and more customers choose alternative channels for shopping, marketers must create multi-channel strategies

\section{Customer shopping experiences}

663 


\section{BJM 16,5}

\begin{tabular}{llll}
\hline Technology & Authors & Retail area & Service platform \\
\hline $\begin{array}{l}\text { Augmented } \\
\text { reality }\end{array}$ & $\begin{array}{l}\text { Poushneh and } \\
\text { Vasquez-Parraga } \\
(2017)\end{array}$ & Apparel & E-shopping \\
& Smink et al. (2019) & Cosmetics & E-shopping
\end{tabular}

664

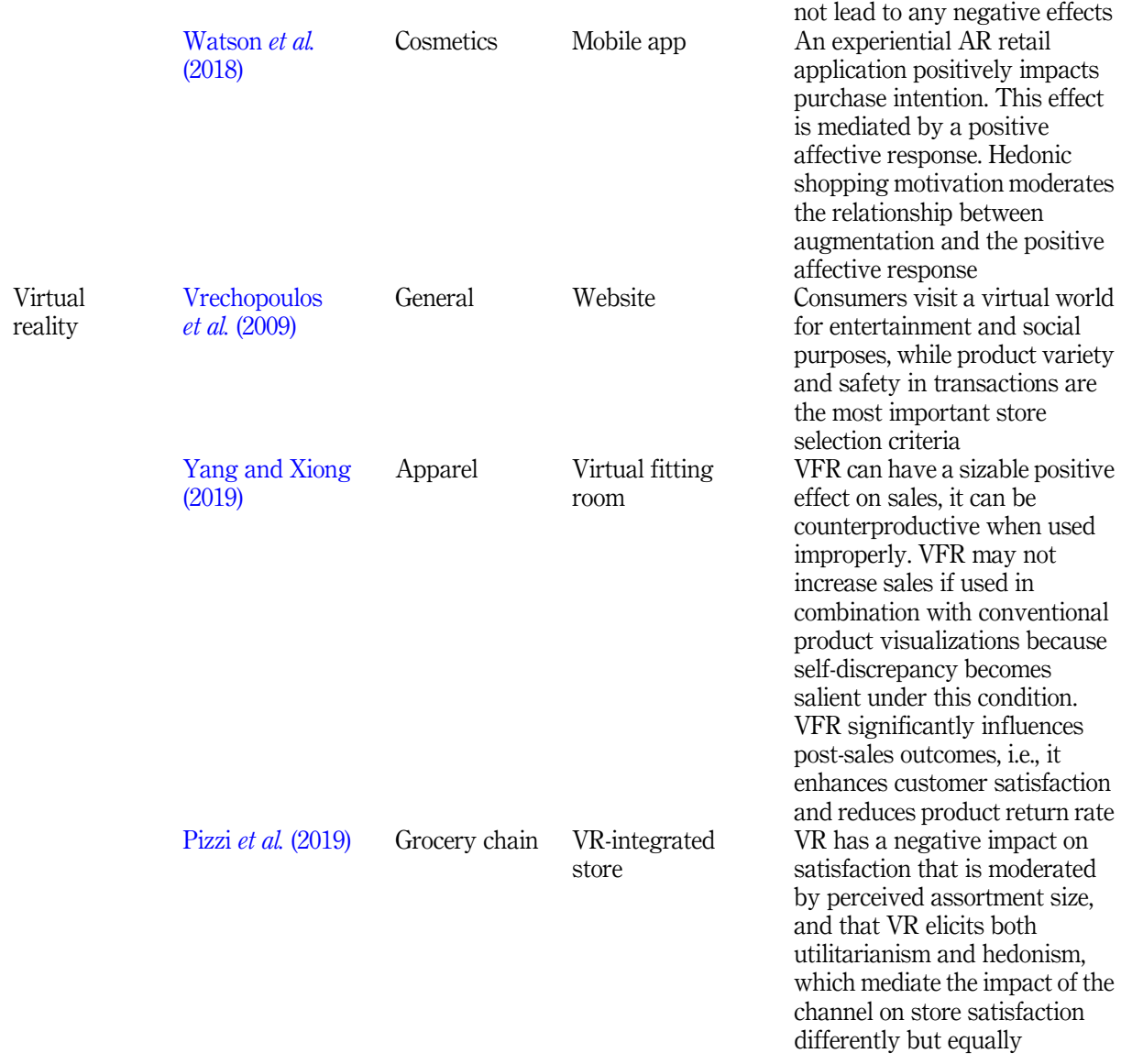

AR shapes user experience, user satisfaction, and willingness to buy

AR enhances perceived informativeness and enjoyment of the shopping experience. AR is perceived as intrusive, but against expectations, this does not lead to any negative effects An experiential AR retail pplication positively impacts is mediated by a positive affective response. Hedonic the relationship between augmentation and the positive response for entertainment and social purposes, while product variety the most important store ion criteria effect on sales, it can be counterproductive when used improperly. VFR may not increase sales if used in combination with conventiona self-discrepancy becomes alient under this condition. post-sales outcomes, i.e., it enhances customer satisfaction VR has a negative impact on .

Table 1.

The customer experience literature on innovative technologies in (continued) retailing 


\begin{tabular}{|c|c|c|c|c|c|}
\hline Technology & Authors & Retail area & Service platform & Key findings & Customer \\
\hline \multirow[t]{3}{*}{$\begin{array}{l}\text { Artificial } \\
\text { intelligence }\end{array}$} & Guzman (2018) & General & $\begin{array}{l}\text { Mobile voice } \\
\text { assistants }\end{array}$ & $\begin{array}{l}\text { Users of mobile assistants } \\
\text { orient toward a technology, } \\
\text { instead of thinking they are } \\
\text { interacting with a human, but, } \\
\text { in contrast to existing research, } \\
\text { attend to different technologies }\end{array}$ & experiences \\
\hline & $\begin{array}{l}\text { Hsiao and Chang } \\
\text { (2019) }\end{array}$ & General & $\begin{array}{l}\text { Digital voice } \\
\text { assistants (DVA) }\end{array}$ & $\begin{array}{l}\text { DVA is a tool that can improve } \\
\text { delivery persons' work and } \\
\text { operational efficiency while that } \\
\text { industry's operators expect } \\
\text { DVA to improve their ability to } \\
\text { serve customers before } \\
\text { operators adopt it }\end{array}$ & \\
\hline & Pillai et al. (2020) & $\begin{array}{l}\text { Shopping } \\
\text { malls and } \\
\text { retail stores }\end{array}$ & $\begin{array}{l}\text { AI-powered } \\
\text { automated store }\end{array}$ & $\begin{array}{l}\text { Consumers' innovativeness and } \\
\text { optimism affect the perceived } \\
\text { ease of use and perceived } \\
\text { usefulness. Insecurity } \\
\text { negatively affects the perceived } \\
\text { usefulness of AI retail stores. } \\
\text { Perceived ease of use, } \\
\text { usefulness, and enjoyment, } \\
\text { customization, and interactivity } \\
\text { are significant predictors of the } \\
\text { shopping intention of } \\
\text { consumers in AI-powered } \\
\text { stores }\end{array}$ & \\
\hline \multirow[t]{4}{*}{$\begin{array}{l}\text { Internet of } \\
\text { Things }\end{array}$} & $\begin{array}{l}\text { Hoffman and } \\
\text { Novak (2018) }\end{array}$ & General & Smart objects & $\begin{array}{l}\text { Four specific consumer } \\
\text { experience assemblages: } \\
\text { enabling experiences, } \\
\text { comprising agentic self- } \\
\text { extension and communal self- } \\
\text { expansion, and constraining } \\
\text { experiences, comprising agentic } \\
\text { self-restriction and communal } \\
\text { self-reduction }\end{array}$ & \\
\hline & $\begin{array}{l}\text { Balaji and Roy } \\
\text { (2017) }\end{array}$ & General & Retail technologies & $\begin{array}{l}\text { Ease of use, superior } \\
\text { functionality, aesthetic appeal, } \\
\text { and presence are key } \\
\text { determinants of value } \\
\text { co-creation for IoT retail } \\
\text { technology }\end{array}$ & \\
\hline & Wu et al. (2017) & General & Smart objects & $\begin{array}{l}\text { A friend-like interaction style } \\
\text { produces more positive brand } \\
\text { warmth and enhances brand } \\
\text { competence and has a positive } \\
\text { effect on users' brand } \\
\text { attachment }\end{array}$ & \\
\hline & & & & (continued) & 1. \\
\hline
\end{tabular}




\section{BJM 16,5}

\begin{tabular}{llll}
\hline Technology & Authors & Retail area & Service platform \\
\hline Blockchain & $\begin{array}{l}\text { Neyer and Geva } \\
(2017)\end{array}$ & $\begin{array}{l}\text { Payment } \\
\text { mechanism }\end{array}$ & $\begin{array}{l}\text { Cryptocurrency; } \\
\text { Bitcoin }\end{array}$
\end{tabular}

Key findings

Blocktech is not superior to existing payment mechanisms, except in certain niche circumstances. Major breakthroughs will be required before adoption becomes widespread

Frey et al. (2016) General Beacon; Mobile app

Air delivery system

Drones Yoo et al. (2018)

General Hwang et al. Food (2019)

Air delivery system
Customers' personal data are protected by a blockchainbased storage network The advantages of speed and environmental friendliness, complexity, performance and privacy risk, affect drone delivery adoption. Personal innovativeness positively affects adoption intention MCI (motivated consumer innovativeness) positively affect attitude and behavioral intentions. Attitude has a positive influence on desire and behavioral intentions

Table 1.

(Schoenbachler and Gordon, 2002) whereby they link their brick-and-mortar store operations with alternatives such as catalogs, call centers, e-commerce, and mobile applications. According to the multi-channel view, the customer gets a diverse experience across channels and acts as an integrator of information, while the omnichannel view extends this further and focuses on bridging the gaps between different channels to provide a consistent and seamless customer experience (Hänninen et al., 2018; Komulainen and Makkonen, 2018; Saghiri et al., 2017).

Marketers also need a customer-centric focus in developing and designing channel alternatives that are successful and effective because they emphasize customer needs (Schoenbachler and Gordon, 2002). A study by Dorman (2013) deliberated research between consumers' direct online interactions and brick-and-mortar retail stores and established a positive relationship between the two indicating that retail stores are attracting customers with a help of online exposure. Frazer and Stiehler (2014) argued how retailers' omnichannel options can influence the shopping experience across the channels. However, these findings only indicate that customers are willing to engage with channels that are offered in omnichannel retailing. In this study, we will delve deeper and explore how different innovative technologies influence customers' channel choices (e.g. between online and offline) and their shopping experience.

\subsection{Customer's value dimensions in shopping}

The concepts of customer experience and customer value are profoundly intertwined because customer perceived value influences cumulative customer experience and vice versa (Helkkula and Kelleher, 2010). Customer value can be understood in terms of how value is delivered through experience, as customers' perceived value and experience are constantly being assessed and modified by their individual and collective life-worlds, both consciously and unconsciously (Helkkula and Kelleher, 2010). Since customer experience is commonly 
perceived as subjective, personal, and internal (Helkkula et al., 2012), the customer's personal and individual living environment forms the environment for creating the value and customer experience (Heinonen et al., 2013). Value is therefore built on the experience extracted from the service (Frow and Payne, 2007; Helkkula and Kelleher, 2010).

Traditionally, value has been divided into two dimensions: utilitarian and hedonic value (e.g. Addis and Holbrook, 2001; Batra and Ahtola, 1991). The utilitarian and hedonic values are an important part of customer experience both in-store and online (e.g. Babin et al., 1994; Holbrook and Hirschman, 1982; Lee and Wu, 2017). Customers use different retail channels at each stage of the shopping journey to meet their utilitarian and hedonic needs to maximize value (e.g. Balasubramanian et al., 2005). These two value dimensions account for why consumers purchase goods and services and perform consumption behaviors (Batra and Ahtola, 1991). These dimensions are not mutually exclusive as both can occur within the same shopping experience (Bradley and Lafleur, 2016); so, for example, the convenience of technology can increase customer's playfulness or the willingness to explore (Ahn et al.,2007).

Consumers who are oriented toward utilitarian benefits are motivated by task-related outcomes such as purchasing products in an efficient and timely manner (Babin et al., 1994). According to Childers et al. (2001), convenience increases search efficiency, and the consumer can choose when and where to shop. The majority of the retail technology offered in-store comprises cost and timesaving technology, and therefore, retailers tend to focus on the utilitarian benefits of technology (Willems et al., 2017). Hedonically oriented shoppers seek a pleasurable experience and the resulting enjoyment (Hirschman and Holbrook, 1982). Pantano and Naccarato (2010) discovered that consumers respond positively to the introduction of new technology because of the enjoyable elements in the shopping process. Research on the importance of an enjoyable experience has increased (Bäckström and Johansson, 2006) since the feeling of enjoyment can add value to the experience, especially to the context of goods and services exhibited (Newsom et al., 2009).

Based on the above discussion, a theoretical framework of customer's shopping experience in the setting of innovative technologies is presented in Figure 1. We conclude that customer experience is always subjective, social, contextual, temporal and holistic. Exploring the customer shopping experience in the context of innovative technologies reveals it is influenced by innovative forms of technology, and furthermore, both influences and is influenced by the channel choice and the customer's value perceptions, in this case particularly by utilitarian and hedonic value dimensions. Below, we briefly present the methodology of the study and then examine the phenomenon empirically with the help of focus group discussions and in-depth personal interviews.

\section{Methodology}

The impact innovative technologies have on customer shopping experiences is an emerging phenomenon and accordingly, an explorative qualitative approach was adopted in this study.

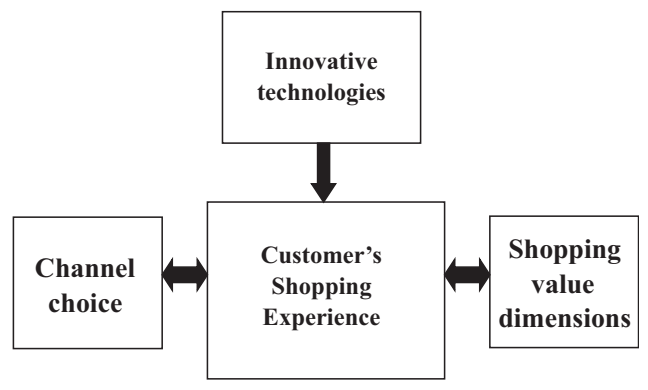

Figure 1.

A theoretical framework of customer's shopping experience in innovative technologies setting 
BJM

16,5

668

The advantage of using qualitative methods in exploratory research is that they enable the handling of the research topic flexibly and inductively, which is integral to revealing an emerging phenomenon (Mack et al., 2005). In addition, qualitative methods allow the researchers to emphasize the qualities of the entities and holistically explore the relevant phenomenon (Denzin and Lincoln, 2008; Gephart, 2004). This qualitative study has characteristics of a phenomenological research strategy, where the views and experiences of the people who participate in the phenomenon being studied are accepted as fact. In phenomenological studies of experiences, an objective outcome cannot be analyzed on the events and their progression, but as an understanding of a researcher, respondent, and reader on the phenomenon (Helkkula et al., 2012). Therefore, the aim is to describe what was experienced and how it was experienced (Teherani et al., 2015). When conducting qualitative research, the goal is not to recruit a fixed number of participants but to gather information of adequate depth to be able to describe the phenomenon being studied (Fossey et al., 2002). The following sub-sections will provide evidence of data collection.

\subsection{Data collection}

Empirical data were collected using two different kinds of qualitative methods (focus groups and interviews) to collect data that offer precise and comprehensive information. The focus group method was used to reveal open-ended thoughts of participants, while a researcher facilitated comprehensive discussion. The method encouraged interaction within groups to generate rich and extensive data (Liamputtong, 2011). The interviews were conducted to complement the focus group data with precise insights from the respondents. Integrating focus group and individual interview data is beneficial for the purposes of data completeness and/or confirmation (Adami, 2005; Halcomb and Andrew, 2005). Although many previous studies have examined consumer shopping experiences using quantitative methods (see, e.g. Pallant et al., 2020; Sands et al., 2016), this study answers the call for more comprehensive qualitative empirical research. Using interviews and focus groups as data collection methods enabled us to harvest various versatile viewpoints and a more comprehensive understanding of customer shopping experiences in the innovative technology setting, than would gathering survey data based on strictly predetermined concepts and models.

The focus groups and individual interviews started with an interactive session where participants were first asked to think of a product they wanted to buy and discuss the process of buying it. The participants were shown brief technology videos in the omni-channel shopping context (Table 2), and a discussion was initiated after each video on the imagined experience of using a certain technology. Two videos were shown of AR technology since literature has demonstrated differences in the usage in-store and online environments (e.g., Dacko, 2017). In the last part of the session, the participants were asked to discuss their choice of product in the first session but to incorporate the newly received information on the innovative technologies into the imagined shopping experience.

This study relies on interviewees' subjective views of the phenomenon, which is common for phenomenological studies, and accordingly, a sample size of approximately six to ten participants was anticipated (Guest et al., 2006; Kuzel, 1999; Morse, 2000). The target group for this study was selected by focusing on those consumers who shop frequently for multiple different purposes, use both online and offline channels, and perceive themselves to be techsavvy. This led to the sample group involving young adults who are predominantly the leaders in terms of profiling technologies into their experiences (Foroudi et al., 2018). To avoid potential bias in the interviews, a multifaceted group of respondents was selected. A total of 17 participants in four focus groups and 10 in-depth interviews were used to collect the data. The participants were recruited through various online portals, for example, an invitation via social media in the form of a Facebook post. 


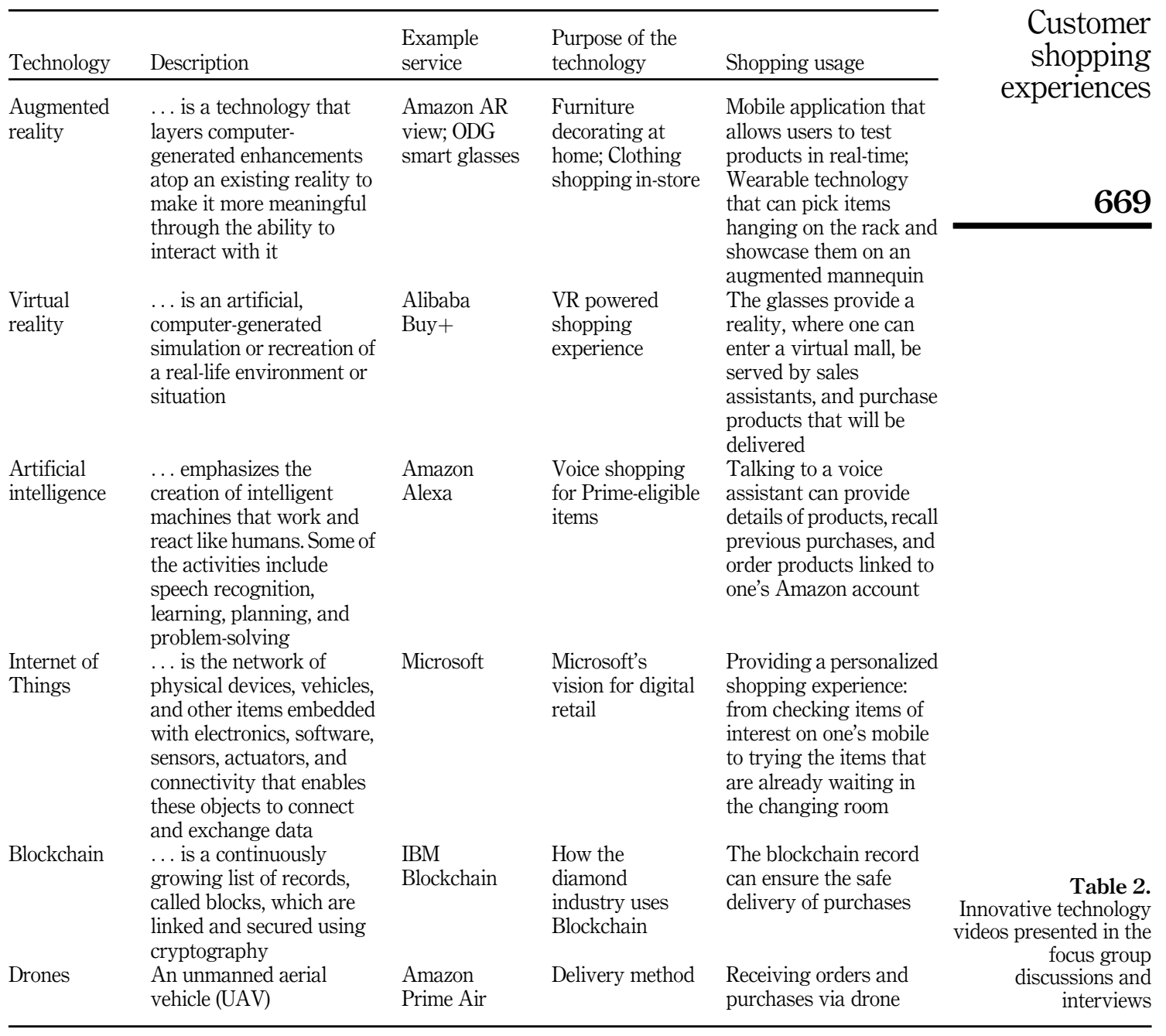

The focus group sessions were conducted in Canada in September 2018, included both genders (53\% females, $47 \%$ males) and young students or professionals aged between 18 and 30 because young consumers are the early adopters of innovative technologies (Pantano and Gandini, 2017). The in-depth interviews were conducted in Finland from December 2019 to January 2020, they also included both genders equally and young students or professionals aged between 18 and 30. Both countries have advanced levels of retail technology where consumers largely pay attention to new technology. Therefore, experiences of current technology and retail trends harvested in these countries experiencing should be informative for practitioners and researchers alike. The interviews were conducted face-to-face, then recorded and transcribed. The interviews lasted between 40 and 54 minutes.

As a phenomenological research strategy describes what was experienced and how it was experienced (Teherani et al., 2015), both in reality and in the imagination (Helkkula et al., 2012), 
BJM

16,5

the session encouraged the participants to describe their imaginary shopping experiences. The participants were asked to imagine their shopping experience in a way that they have not seen before in the context of innovative technologies, thus this topic could be integrated into a new semantic context (Madison, 1988). Following semi-structured interview guidelines, the interviewees were probed for further thoughts on certain topics, allowing the discussion to flow into focused, conversational two-way communication.

Once the interviews started providing collectively similar outcomes, the data had reached thematic saturation (Green and Thorogood, 2004). Conducting more interviews would not necessarily have led to new insights and there would be no further emergent patterns in the data (Gaskell, 2000). The data collection was stopped once the interviewees mentioned similar themes multiple times, such as "value elements related to the customer experience." The themes were noticed after eight interviews, which is a similar outcome to that noted by Guest et al. (2006) who discovered basic elements for their themes emerging as early as after six interviews.

\subsection{Data analysis}

The abductive approach to research is the process of systematic combining that demands the researcher moves between empirical reality, relevant literature, and theoretical framework (Dubois and Gadde, 2002). The abductive approach was used to better understand the phenomenon of customer shopping experiences "using the participants' own words within the context" (Ozuem et al., 2016, p. 6). It is the process of systematic combining that involves various research activities and going back and forth between theory and empirical observations to expand the understanding of both the theory and empirical phenomenon (Dubois and Gadde, 2002). Such a method shows results that have linked topics that have not previously been associated with one another (Reichertz, 2004). Data in this kind of research are sufficiently detailed and rich, which is useful to explore the phenomenon to identify themes that are located in a conceptual framework.

The data were analyzed by one researcher, who was also responsible for the data collection. To improve the reliability of the findings, a second researcher reviewed the interpretations made by the first. The researchers reanalyzed the data together if the interpretations conflicted to obtain a consensus. Content analysis was implemented to identify the common themes. These themes were identified by summarizing the data and applying codes (Carney, 1990). In qualitative research, coding is both defining what the analyzed data is about, and identifying a passage in the text, searching and identifying concepts, and finding relations between them (Gibbs, 2007). The results of this study reflected the imagined experiences of the participants who believed innovative technologies would affect their shopping experiences. Having such an approach is evident since these forms of technology are only emergent and are mostly not yet in general use in retailing. However, the actual experiences based on other technologies participants have used, and their previous shopping experiences, supported these imaginary experiences, thus providing plausible and interesting findings related to the topic.

\section{Results}

Below we elaborate on the three themes that emerged from the data: shopping channels using innovative technology, the value dimensions of convenience and entertainment in relation to customer experience, and social interaction between people and technology.

\subsection{Shopping channels using innovative technology}

All participants preferred the retail channel that they already used for shopping, either online or in-store. The participants envisioned using the innovative technologies more with their 
mobile phones, which is in line with the increasing use of mobile channels for shopping acknowledged in previous research (Guzman, 2018; Watson et al., 2018). The data analysis revealed the online channel was considered more convenient, but in-store shopping was seen as more trustworthy. However, the participants said they would use both channels for buying, as both had their advantages. This finding is aligned with the previous research where customers like to use both channels for buying to maximize their utilitarian and hedonic value needs (e.g. Balasubramanian et al., 2005). The following excerpt on the use of augmented reality highlights how the innovative technologies can be used to implement both channel experiences at the same time:

It (AR) is kind of like in-store and online connecting because if you do not want to go outside you just take it like... it's actually an in-store vibe, it's kind of the same thing. (Participant 1, focus group A)

Our findings show that each form of technology has unique features that may be successful in a certain channel, which is a critical part of the experience. Some of the technologies were considered successful in only one channel, for example, VR was fun and entertaining in-store technology whereas the Blockchain and drones were seen as useful in buying everyday items using online channels. Past research shows that consumers endorse the use of new technologies in-store (Pantano, 2009) for immediate possession, and online shopping is influenced by variety-seeking behavior (Rohm and Swaminathan, 2004). The AI, IoT, and AR forms of technology sat somewhat between the two channels, each technology fitting both online and offline channels. In addition, our results are in line with the study of Wolny and Charoensuksai (2014) that found that consumers take numerous routes to purchase a product owing to an increasing number of technologies and channels:

I think I would look for products online for a certain need, and if I cannot find what I am looking for,

I would go to an actual store and try out the product there. (Interviewee 1)

In terms of channels, innovative technologies appear to play a different role online and in-store, as well as in multi-channel contexts. The diversity of different channels and combinations of them preferred by customers requires that retailers adopt a holistic strategy on the use of innovative technology through channels.

\subsection{Value dimensions of convenience and entertainment for customer experience}

The data analysis revealed convenience and entertainment to be the most essential utilitarian and hedonic values in customer experience. The Blockchain and drones were considered to provide convenient value, VR provided entertainment, and IoT, AI and AR considered to provide both values. The theme of convenience was related to accomplishing shopping tasks in a timely manner, anywhere and anytime. The shopping process could involve less effort using the various technologies because they provide quick solutions to the participants' problems. For example, a store with IoT sensors could provide convenience because it could limit the consumer's shopping workload by providing the store assistants information to help them understand the consumer's wishes and choices. In the case of AI, where shopping is easily completed with the voice assistant, the process of buying could be convenient for the customer as the following quotation reveals:

Shopping is very easy, and I was also thinking that it would be good to have certain collaborations between companies, for example, I could order food faster from the grocery store by just saying aloud "I need this and this" and then I could receive the products. (Interviewee 9)

The entertainment theme included enjoying using the technology, and the goal was not just to purchase but also to enjoy the shopping journey. Entertainment is related to hedonic value in shopping: hedonically oriented buyers seek a pleasurable experience and the enjoyment

\section{Customer shopping experiences}


BJM

16,5

resulting from the fun (Hirschman and Holbrook, 1982). Our data show shopping was seen as an adventure, for example, VR glasses could provide a unique way of buying. This strengthens the theory that innovative technologies affect consumers' shopping behavior because consumers respond positively to the introduction of the forms of technology mentioned owing to the elements of enjoyment they contribute to the shopping process (Pantano and Naccarato, 2010).

Yeah, it looks fun. If I had that [VR service], I would definitely try to buy something. (Participant 2, focus group A)

However, while there was a clear distinction between convenient and entertaining experiences, the participants did not place as much emphasis on entertainment as they did on convenience. Past research confirms that retailers tend to focus on the utilitarian benefits of technologies because the majority of the retail technology offered in-store is there to offer cost and timesaving benefits (Willems et al., 2017). As an example of the importance of convenience, participants presumed that drones could be very useful and convenient for shopping:

I think the Amazon Air is kind of cool because now all of a sudden you can buy something online and then get it in two hours. You do not have to wait a week or two weeks. (Participant 2, focus group D)

Additionally, the data revealed that the two value dimensions were not mutually exclusive for participants, as both could occur within the same shopping experience. This finding is in line with that in the study of Bradley and Lafleur (2016) suggesting that hedonic and utilitarian value may be present in the overall offline retail service experience. This research strengthens the previous theory by adding the innovative technology setting to the research as participants described, for example, revealing how an AR mobile app is simultaneously convenient for re-planning purchases and also fun to play around with. Even though convenience was emphasized in the participants' shopping experience, enjoyment was also present:

I had to buy a suit for my presentation, so I bought everything in one hour. I bought shoes and a suit and then I really enjoyed it! I do not like spending a lot of time, just go there and see the stuff. (Participant 3, focus group D)

\subsection{Social interaction with humans and technology}

As the third critical factor, the data revealed that social aspects play a highly important role in the shopping experience. The shopping experience is heavily affected by the consumer's social context that manifests in the opinions and experiences of other people. In addition, the social aspect was very closely linked to the participants' channel preference. This is probably because shopping is considered a social experience where a companion can influence a purchase decision, reduce stress levels, and make shopping more enjoyable (Borges et al., 2010). During online shopping, there is less human interaction than during an in-store experience and consequently, some participants preferred in-store shopping.

I prefer in-store because the staff can help me. When I go to a store, I have not made up my mind what I am going to buy before I am there. (Interviewee 7)

For some participants, however, the shopping experience is a very personal thing and they do not want any social communication or disruption when they are shopping. Therefore, online shopping is preferable for them, as the quotation below demonstrates:

I do not want to communicate with, um, people in the store. I do not know why but I feel a little bit more satisfied by doing online shopping. (Participant 1 , focus group A) 
In some cases, the social interaction was viewed as being with the technology itself (e.g. a robot) rather than with a person. AR, VR and AI technologies were linked to interactions with humans whereas the interactions with IoT, the Blockchain and drones were considered to happen with the technology (in this case a service or robot). The innovative technologies were found to be enjoyable, especially in the case of AI (such as voice assistant Alexa), but they were not considered to be useful with purchase decisions as they were still considered too novel in a shopping context.

It's weird to be talking [to AI technology], it's awkward for me. I am a visual person so I need to see what I buy; you know I just cannot buy it through robots. (Participant 3, focus group A)

The aspects related to social interaction, therefore, bring out the dilemma between people and technology. For example, does the technology diminish social interaction with real people? and does the technology provide interaction with people or is it purely a purely technologyinteraction? Some of the participants said they enjoyed using technologies and some have a negative view of using it. Regardless, they still long for some level of social interaction, which is common in shopping (see, e.g. Arnold and Reynolds, 2003). Participants thought the technologies added novelty to the shopping experience so they had difficulty in familiarizing themselves with interacting solely with the technology. This could be why opportunities to socialize were highlighted by the participants. This contradiction creates challenges for the retailers in adopting and using innovative technology.

\section{Discussion and conclusions}

This study aimed to explore and understand customers' shopping experience with innovative technologies. Specifically, the purpose was to understand how do innovative technologies influence the customer shopping experience. The data were collected qualitatively through interviewing young adults who considered themselves tech-savvy shoppers. This study focused on six key technologies: augmented reality, virtual reality, artificial intelligence, the internet of Things, the Blockchain, and drones. The data gathered reveal three critical factors in a customer's shopping experience in the context of these technologies; (1) channel choice, (2) value dimensions related to convenience and enjoyment, and (3) social interaction. All factors are highly intertwined and influence each other and are presented in the empirically grounded framework (Figure 2). The framework in the figure also reveals how the use of the innovative technologies varies in different channels, what kind of value the technologies provide, and what kind of social interaction takes place when using different technology. The key findings and their implications for theory and practice are discussed and summarized below.

First, the shopping experience with innovative technology varies according to the channel choice. Customers want a smooth omnichannel experience in both online and offline environments. This is similar to customers' shopping behavior in general; the majority use both online and in-store channels either separately or in combination, while shopping (see also Balasubramanian et al., 2005). However, some technologies seem better suited to the online channels and some to in-store shopping, and thus it can be hard to provide a suitable shopping experience because of the customer's expectations and channel preferences. Therefore, it is important to recognize which forms of technology work best in which environment and how their specific characteristics could be best utilized in each channel to provide an improved customer experience.

Second, the two value dimensions of convenience and entertainment were found to be critically important aspects of the customer experience. These value dimensions stem from the utilitarian and hedonic shopping value research (Batra and Ahtola, 1991; Lee and Wu, 2017) but in the context of our study, convenience and entertainment seem to be more apt. 


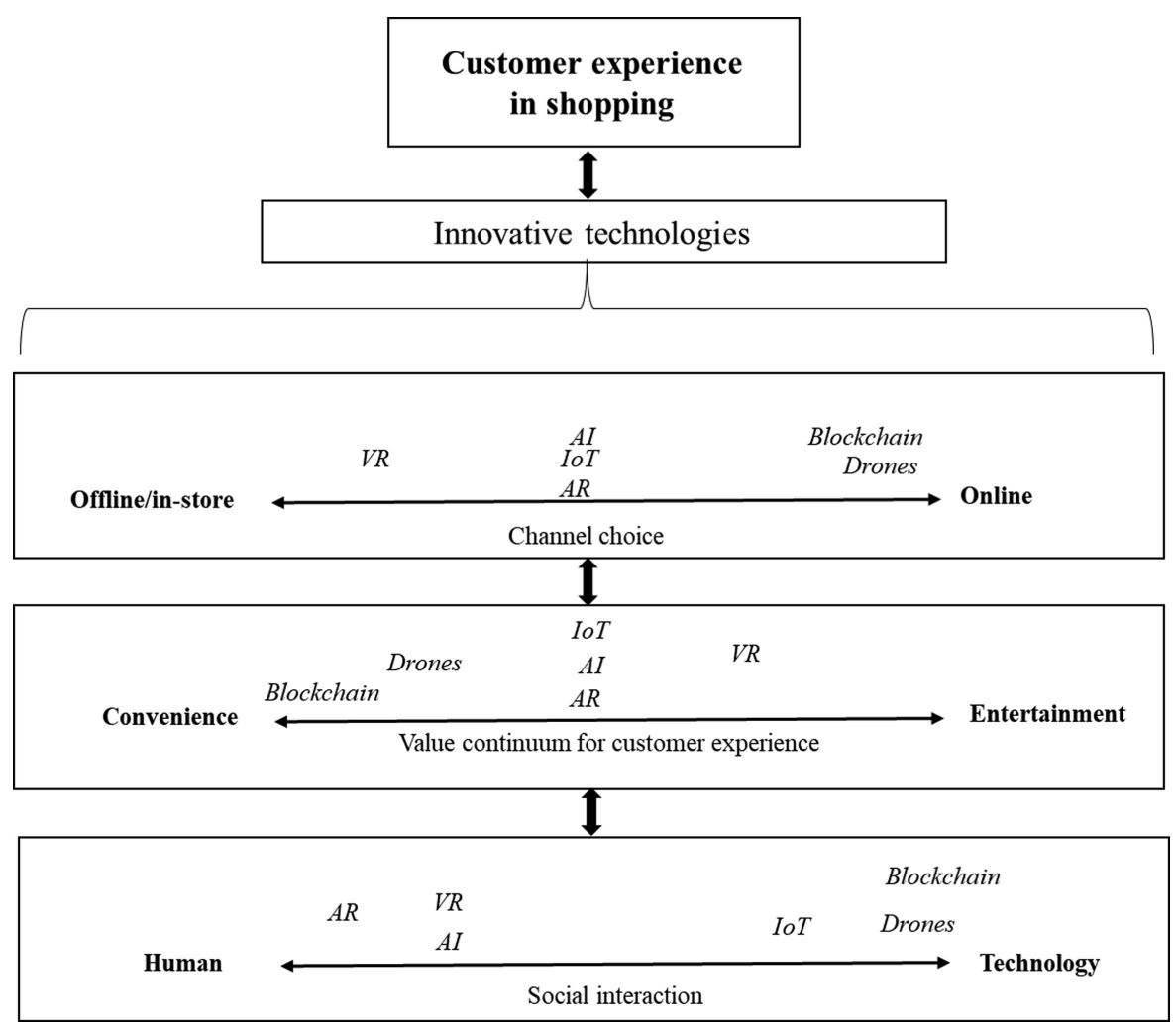

Figure 2.

Empirically grounded framework of critical factors in customer shopping experiences as they relate to innovative technologies
The findings showed that in accordance with previous research, that these two dimensions can occur in the same shopping experience and that all the technologies examined can provide both convenient and entertaining experiences (e.g. Bradley and Lafleur, 2016). Still, some examples of technology seem to provide a more convenient experience (e.g. the Blockchain and drones) and some more enjoyment (e.g. VR). However, in our respondents emphasized the importance of convenience. This finding slightly conflicts with past research suggesting that increased enjoyment while shopping can add more value to the experience (Bäckström and Johansson, 2006) and influence subsequent buying behavior (Pantano and Naccarato, 2010). It can be assumed that this emphasis was probably because the technologies in question provided more task-related outcomes rather than entertainment. This result means that the innovative technologies could make the customer shopping experience less rewarding, especially, if they proved incapable of providing the shopping value the customer desires.

Third, social interaction including interactions between humans and technology emerged in the empirical study as a very important factor. The effect is closely related to the channel through which the shopping is done (i.e. online shopping has less human interaction compared to the in-store form) and whether the technology provides interaction with humans or whether the available interaction is purely provided by the technology. Our data provided rather controversial perspectives on social interaction. Some customers need social interaction with people even though they find it easy and convenient to use technology 
during shopping. In contrast, for some customers shopping is a very personal experience, and such people might find social interaction is disturbing and might thus prefer online shopping and using forms of technology without human contact. However, while the study showed that technology-provided interaction was enjoyable, which has been determined by past research (Pantano and Naccarato, 2010), it did not result in a positive shopping experience. The key question is thus: how might social interaction be transformed from human-centered to technology-provided in a manner that could replace actual human contact but at the same time fulfill customer needs for social interaction? We suggest that social interaction and all the contradictions related to it are one of the most important aspects to be considered when developing innovative technologies for successful commercial use and an improved customer experience.

Overall, our study contributes to the research on customer experience by offering an empirically grounded framework to help understand customer shopping experiences in a new kind of technological setting (Figure 2). The results show how customers could use innovative technologies when shopping and provides new knowledge on customer experience in the future when the innovative technologies featured will inevitably be intertwined with the shopping experience.

For retail managers, this study shows how they can plan to sell their products and services by using the most suitable innovative technology to serve their customers. The imagined experiences of using novel technologies pave the way to new point-of-sale and innovation opportunities in channel management. Retail managers could entice customers to their shopping space by creating an immersive experiential environment, which in turn could increase brand awareness and customer loyalty. However, the scenarios examined using such innovative technologies during the data collection were imaginary, and the technologies examined are not yet widely available in retailing. Technology that has the support of retailers and early-adopter consumers could encourage curiosity among a broader set of shoppers that leads the latter group to experiment with those technologies. The more experience consumers have with shopping using innovative technologies, the greater will be the opportunity for retailers to create a competitive advantage.

Finally, although this study has meaningful implications for both theory and practice, some limitations could help formulate important questions for further research. Data were collected by showing videos to participants and one or two videos presenting each form of technology cannot capture the entire capability of that technology. For example, in this study, the video showcasing AI technology focused on voice assistance in shopping. Furthermore, the study only included young adults aged between 18 and 30 who shop and use technology differently than other age groups. By researching other age groups, there might be new insights on the consumer experience with innovative technology. Additionally, the study did not include the analysis of how and where the technologies were used similarly or differently in online as opposed to in-store channels. Research on this could provide feasibility information to retailers who rely on omnichannel or single-channel retailing. Finally, future research should focus on employing quantitative means to understand whether a consumer's shopping experience can be simultaneously convenient and entertaining to enable the results of the current study to be generalized to a larger sample population.

\section{References}

Adami, M.F. (2005), "The use of triangulation for completeness purposes", Nurse Research, Vol. 12 No. 4, pp. 19-29.

Addis, M. and Holbrook, M.B. (2001), "On the conceptual link between mass customisation and experiential consumption: an explosion of subjectivity", Journal of Consumer Behavior, Vol. 1 No. 1, pp. 50-66. 
BJM

16,5

Ahn, T., Ryu, S. and Han, I. (2007), "The impact of web quality and playfulness on user acceptance of online retailing", Information Management, Vol. 44 No. 3, pp. 263-275.

Arnold, M.J. and Reynolds, K. (2003), "Hedonic shopping motivations", Journal of Retailing, Vol. 79 No. 2, pp. 77-95.

Bäckström, K. and Johansson, U. (2006), "Creating and consuming experiences in retail store environments: comparing retailer and consumer perspectives", Journal of Retailing and Consumer Services, Vol. 13 No. 1, pp. 417-430.

Babin, B.J., Darden, W.R. and Griffin, M. (1994), "Work and/or fun: measuring hedonic and utilitarian shopping value”, Journal of Consumer Research, Vol. 20 No. 4, pp. 644-656.

Balaji, M.S. and Roy, S.K. (2017), "Value co-creation with Internet of things technology in the retail industry”, Journal of Marketing Management, Vol. 33 Nos 1-2, pp. 7-31.

Balasubramanian, S., Raghunathan, R. and Mahajan, V. (2005), "Consumers in a multi-channel environment: product utility, process utility, and channel choice", Journal of International Marketing, Vol. 19, pp. 12-30.

Barlow, A.K.J., Siddiqui, N.Q. and Mannion, M. (2004), "Developments in information and communication technologies for retail marketing channels", International Journal of Retail Distribution and Management, Vol. 32 No. 3, pp. 157-163.

Batra, R. and Ahtola, O.T. (1991), "Measuring the hedonic and utilitarian sources of consumer attitudes", Marketing Letters, Vol. 2 No. 2, pp. 159-70.

Borges, A., Chebat, J.-C. and Babin, B.J. (2010), "Does a companion always enhance the shopping experience?", Journal of Retailing and Consumer Services, Vol. 17 No. 4, pp. 294-299.

Bradley, G.T. and Lafleur, E.K. (2016), "Toward the development of hedonic-utilitarian measures of retail service", Journal of Retailing and Consumer Services, Vol. 32, pp. 60-66.

Carney, T.F. (1990), Collaborative Inquiry Methodology, University of Windsor, Ontario.

Carù, A. and Cova, B. (2003), "Revisiting consumption experience: a more humble but complete view of the concept", Marketing Theory, Vol. 3 No. 2, pp. 267-286.

Carù, A., Caru, A. and Cova, B. (2007), Consuming Experience, Routledge, London.

Childers, T.L., Carr, C.L., Peek, J. and Carson, S. (2001), "Hedonic and utilitarian motivations for online retail shopping behaviour", Journal of Retailing, Vol. 77, pp. 511-535.

Dacko, S.G. (2017), "Enabling smart retail settings via mobile augmented reality shopping apps", Technological Forecasting and Social Change, Vol. 124, pp. 243-256.

Denzin, N.K. and Lincoln, Y.S. (2008), The Landscape of Qualitative Research, 3rd ed., Sage Publication, Thousanks Oaks, CA.

Dorman, A.J. (2013), "Omni-channel retail and the new age consumer: an empirical analysis of directto-consumer channel interactions in the retail industry", CMC Senior Theses, Paper 590.

Dube, A. and Helkkula, A. (2015), "Service experiences beyond the direct use: indirect customer use experiences of smartphone apps", Journal of Service Management, Vol. 26 No. 2, pp. 224-248.

Dubois, A. and Gadde, L.-E. (2002), "Systematic combining: an abductive approach to case research", Journal of Business Research, Vol. 55 No. 7, pp. 553-560.

Edvardsson, B., Enquist, B. and Johnston, R. (2005), "Cocreating customer value through hyperreality in the prepurchase service experience", Journal of Service Research, Vol. 8 No. 2, pp. 149-61.

ERC (2016), The best of virtual and augmented reality, available at: https://ncerc.org/the-best-ofvirtual-and-augmented-reality/ (accessed 14 May 2020).

Foroudi, P., Gupta, S., Sivarajah, U. and Broderick, A. (2018), "Investigating the effects of smart technology on customer dynamics and customer experience", Computers in Human Behavior, Vol. 80, pp. 271-282.

Fossey, E., Harvey, C., McDermott, F. and Davidson, L. (2002), "Understanding and evaluating qualitative research", Australian and New Zealand Journal of Psychiatry, Vol. 36, pp. 717-732. 
Frazer, M. and Stiehler, B.E. (2014), "Omnichannel retailing: the merging of online and off-line environment", Global Conference in Business and Finance Proceedings, Vol. 9 No. 1, pp. 655-657.

Frey, R.M., Vuckovac, D. and Ilic, A. (2016), "A secure shopping experience based on blockchain and beacon technology", in 10th ACM Conference in Recommendation Systems, RECSYS 2016, Boston, MA, USA.

Frow, P. and Payne, A. (2007), "Towards the 'perfect' customer experience", Journal of Brand Management, Vol. 15, pp. 89-101.

Gaskell, G. (2000), "Individual and group interviewing”, in Bauer, M. and Gaskell, G. (Eds), Qualitative Researching with Text, Image and Sound, Sage Publications, London, pp. 38-56.

Gephart, R.P. (2004), "Qualitative research and the academy of management journal", Academy of Management Journal, Vol. 47 No. 4, pp. 454-462.

Gibbs, G. (2007), Analyzing Qualitative Data, Sage Publications, London.

Green, J. and Thorogood, N. (2004), Qualitative Methods for Health Research, Sage Publications, London.

Grewal, D., Roggeveen, A.L. and Nordfält, J. (2017), "The future of retailing”, Journal of Retailing, Vol. 93 No. 1, pp. 1-6.

Grewal, D., Hulland, J., Kopalle, P.K. and Karahanna, E. (2020), "The future of technology and marketing: a multidisciplinary perspective", Journal of the Academy of Marketing Science, Vol. 48, pp. 1-8.

Guest, G., Bunce, A. and Johnson, L. (2006), "How many interviews are enough? An experiment with data saturation and variability", Field Methods, Vol. 18 No. 1, pp. 59-82.

Guzman, A.L. (2018), "Voices in and of the machine: source orientation toward mobile virtual assistants", Computers in Human Behavior, Vol. 90, pp. 343-350.

Hänninen, M., Smedlund, A. and Mitronen, L. (2018), "Digitalization in retailing: multi-sided platforms as drivers of industry transformation", Baltic Journal of Management, Vol. 13 No. 2, pp. 152-168.

Halcomb, E.J. and Andrew, S. (2005), "Triangulation as a method for contemporary nursing research", Nurse Research, Vol. 13 No. 2, pp. 71-82.

Heinonen, K., Strandvik, T., Mickelsson, K., Bo, E., Sundstrom, E. and Andersson, P. (2010), "A customer-dominant logic of service", Journal of Service Management, Vol. 21 No. 4, pp. 531-548.

Heinonen, K., Strandvik, T. and Voima, P. (2013), "Customer dominant value formation in service", European Business Review, Vol. 25 No. 2, pp. 104-123.

Helkkula, A. and Kelleher, C. (2010), "Circularity of customer service experience and customer perceived value”, Journal of Customer Behavior, Vol. 9 No. 1, pp. 37-53.

Helkkula, A., Kelleher, C. and Pihlström, M. (2012), "Characterizing value as an experience: implications for service researchers and managers", Journal of Service Research, Vol. 15 No. 1, pp. 59-75.

Hirschman, E.C. and Holbrook, M.B. (1982), "Hedonic consumption: emerging concepts, methods, and propositions”, Journal of Marketing, Vol. 46 No. 3, pp. 92-101.

Hoffman, D.L. and Novak, T.P. (2018), "Consumer and object experience in the Internet of Things: an assemblage theory approach", Journal of Consumer Research, Vol. 44 No. 6, pp. 1178-1204.

Holbrook, M.B. and Hirschman, E.C. (1982), "The experiential aspects of consumption: consumer fantasies, feelings and fun”, Journal of Consumer Research, Vol. 9 No. 2, pp. 132-140.

Hoyer, W.D., Kroschke, M., Schmitt, B., Kraume, K. and Shankar, V. (2020), "Transforming the customer experience through new technologies”, Journal of Interactive Marketing, Vol. 51, pp. 57-71.

Hsiao, W.-H. and Chang, T.-S. (2019), "Exploring the opportunity of digital voice assistants in the logistics and transportation industry", Journal of Enterprise Information Management, Vol. 32 No. 6, pp. 1034-1050. 
BJM

16,5

Hwang, J., Kim, H. and Kim, W. (2019), "Investigating motivated consumer innovativeness in the context of drone food delivery services", Journal of Hospitality and Tourism Management, Vol. 38, pp. 102-110.

Kang, J.M. (2014), "Augmented reality and motion capture apparel e-shopping values and usage intention”, International Journal of Clothing Science and Technology, Vol. 26 No. 6, pp. 486-499.

Kim, J. and Forsythe, S. (2008), "Adoption of virtual reality try-on technology for online apparel shopping”, Journal of Interactive Marketing, Vol. 22 No. 2, pp. 45-59.

Komulainen, H. and Makkonen, H. (2018), "Customer experience in omni-channel banking services", Journal of Financial Services Marketing, Vol. 23, pp. 190-199.

Komulainen, H. and Saraniemi, S. (2019), "Customer centricity in mobile banking: a customer experience perspective”, International Journal of Bank Marketing, Vol. 37 No. 5, pp. 1082-1102.

Kuzel, A.J. (1999), "Sampling in qualitative inquiry", in Crabtree, B.F. and Miller, W.L. (Eds), Doing Qualitative Research, 2nd ed., Sage Publications, Thousand Oaks, CA, pp. 33-45.

Lee, C.-H. and Wu, J.J. (2017), "Consumer online flow experience: the relationship between utilitarian and hedonic value, satisfaction and unplanned purchase", Industrial Management and Data Systems, Vol. 117 No. 10, pp. 2452-2467.

Liamputtong, P. (2011), Focus Group Methodology: Principles and Practice, Sage Publications, London.

Lipkin, M. (2016), "Customer experience formation in today's service landscape”, Journal of Service Management, Vol. 27 No. 5, pp. 678-703.

Mack, N., Woodsong, C., MacQueen, K.M., Guest, G. and Namey, E. (2005), Qualitative Research Methods: A Data Collector's Field Guide, Family Health International, North Carolina.

Madison, G.B. (1988), The Hermeneutics of Postmodernity: Figures and Themes, Indiana University Press, Indianapolis.

McKinsey (2020), Personalizing the customer experience: driving differentiation in retail, available at: https:/www.mckinsey.com/industries/retail/our-insights/personalizing-the-customerexperience-driving-differentiation-in-retail\# (accessed 28 January 2021.

Morse, J.M. (2000), "Determining sample size", Qualitative Health Research, Vol. 10 No. 1, pp. 3-5.

Newsom, M.K., Collier, D.A. and Olsen, E.O. (2009), "Using 'biztainment' to gain competitive advantage", Business Horizons, Vol. 52, pp. 167-176.

Neyer, G. and Geva, B. (2017), "Blockchain and payment systems: what are the benefits and costs?", Journal of Payments Strategy Systems, Vol. 11 No. 3, pp. 215-225.

Oh, H., Yoon, S. and Shyu, C. (2008), "How can virtual reality reshape furniture retailing?", Clothing and Textile Research Journal, Vol. 26 No. 2, pp. 1443-163.

Ozuem, W., Pinho, C.A. and Azemi, Y. (2016), "User-generated content and perceived customer value", in Ozuem, W. and Bowen, G. (Eds), Competitive Social Media Marketing Strategies, pp. 50-63.

Pallant, J.I., Sands, S.J., Ferraro, C.R. and Pallant, J.L. (2020), "Self-selection and purchase value of research shoppers", International Journal of Retail and Distribution Management, Vol. 48 No. 8 , pp. 845-863.

Pantano, E. and Gandini, A. (2017), "Exploring the forms of sociality mediated by innovative technologies in retail settings", Computers in Human Behavior, Vol. 77, pp. 367-373.

Pantano, E. and Naccarato, G. (2010), "Entertainment in retailing: the influences of advanced technologies", Journal of Retailing and Consumer Services, Vol. 17 No. 3, pp. 200-204.

Pantano, E. and Viassone, M. (2014), "Demand pull and technology push perspective in technologybased innovations for the points of sale: the retailers evaluation", Journal of Retailing and Consumer Services, Vol. 21 No. 1, pp. 43-47.

Pantano, E. (2009), “Augmented reality in retailing of local products of Magna Graecia: consumer's response”, International Journal of Management, Vol. 11, pp. 206-213. 
Pillai, R., Sivathanu, B. and Dwivedi, Y.K. (2020), "Shopping intention at AI-powered automated retail stores (AIPARS)", Journal of Retailing Consumer Services, Vol. 57, pp. 1-15.

Pine, B.J. and Gilmore, J.H. (1998), The Experience Economy: Work Is Theater and Every Business a Stage, Harvard Business School Press, Cambridge, MA.

Pizzi, G., Scarpia, D., Pichierric, M. and Vannucci, V. (2019), "Virtual reality, real reactions?: Comparing consumers' perceptions and shopping orientation across physical and virtual-reality retail stores", Computers in Human Behavior, Vol. 96, pp. 1-12.

Poushneh, A.Z. and Vasquez-Parraga, A.Z. (2017), "Discernible impact of augmented reality on retail customer's experience, satisfaction and willingness to buy", Journal of Retailing and Consumer Services, Vol. 34, pp. 229-234.

Rangaswamy, A., Moch, N., Felten, C., van Bruggen, G., Wieringa, J.E. and Wirtz, J. (2020), "The role of marketing in digital business platforms", Journal of Interactive Marketing, Vol. 51, pp. 72-90.

Reichertz, J. (2004), "Induction, deduction, abduction", in Flick, U. (Ed.), Sage Publications, London, pp. 123-135.

Rohm, A.J. and Swaminathan, V. (2004), "A typology of online shoppers based on shopping motivation”, Journal of Business Research, Vol. 57 No. 7, pp. 748-757.

Saghiri, S., Wilding, R., Mena, C. and Bourlakis, M. (2017), “Toward a three-dimensional framework for omni-channel”, Journal of Business Research, Vol. 77, pp. 53-67.

Sands, S., Ferraro, C., Campbell, C. and Pallant, J. (2016), "Segmenting multichannel consumers across search, purchase and after-sales", Journal of Retailing and Consumer Services, Vol. 33, pp. 62-71.

Schoenbachler, D.D. and Gordon, G.L. (2002), "Multi-channel shopping: understanding what drives channel choice", Journal of Consumer Marketing, Vol. 19 No. 1, pp. 42-53.

Smink, A.R., Frowijn, S., van Reijmersdal, E.A., van Noort, G. and Neijens, P.C. (2019), "Try online before you buy: how does shopping with augmented reality affect brand responses and personal data disclosure”, Electronic Commerce and Research Applications, Vol. 35, pp. 1-10.

Teherani, A., Martimianakis, T., Stenfors-Hayes, T., Wadhwa, A. and Varpio, L. (2015), "Choosing a qualitative research approach", Journal of Graduate Medical Education, Vol. 7, pp. 669-670.

Tynan, C. and McKechnie, S.A. (2009), "Experience marketing: a review and reassessment", Journal of Marketing Management, Vol. 25 Nos 5/6, pp. 501-517.

Verhoef, P.C., Lemon, K.N., Parasuraman, A., Roggeveen, A., Tsiros, M. and Schlesinger, L.A. (2009), "Customer experience creation: determinants, dynamics and management strategies", Journal of Retailing, Vol. 85 No. 1, pp. 31-41.

Vrechopoulos, A., Apostolou, K. and Koutsiouris, V. (2009), "Virtual reality retailing on the web: emerging consumer behavioural patterns", International Review of Retail Distribution and Consumer Research, Vol. 19 No. 5, pp. 469-482.

Watson, A., Alexander, B. and Salavati, L. (2018), "The impact of experiential augmented reality applications on fashion purchase intention", International Journal of Retail Distribution and Management, Vol. 48 No. 5, pp. 433-451.

Willems, K., Smolders, A., Brengman, M., Luyteb, K. and Schöning, J. (2017), "The path-to-purchase is paved with digital opportunities: an inventory of shopper-oriented retail technologies", Technological Forecasting and Social Change, Vol. 124, pp. 228-242.

Wolny, J. and Charoensuksai, N. (2014), "Mapping customer journeys in multichannel decisionmaking", Journal of Direct, Data and Digital Marketing Practices, Vol. 15, pp. 317-326.

Wu, J., Chen, J. and Dou, W. (2017), "The Internet of Things and interaction style: the effect of smart interaction on brand attachment", Journal of Marketing Management, Vol. 33 Nos 1-2, pp. 61-75.

Yang, S. and Xiong, G. (2019), "Try it on! Contingency effects of virtual fitting rooms", Journal of Management Information Systems, Vol. 36 No. 3, pp. 789-822. 
BJM

16,5

Yoo, W., Yu, E. and Jung, J. (2018), "Drone delivery: factors affecting the public's attitude and intention to adopt", Telematics Information, Vol. 35, pp. 1687-1700.

\section{Further reading}

Deloitte (2016), "Retail trends in 2016", available at: https://www2.deloitte.com/uk/en/pages/consumerbusiness/articles/retail-trends-2016.html (accessed 28 September 2020).

\section{Corresponding author}

Marianne Ylilehto can be contacted at: Marianne.ylilehto@oulu.fi

For instructions on how to order reprints of this article, please visit our website: www.emeraldgrouppublishing.com/licensing/reprints.htm Or contact us for further details: permissions@emeraldinsight.com 